\title{
POZIOM WIEDZY STUDENTÓW STUDIÓW MEDYCZNYCH I NIEMEDYCZNYCH W ZAKRESIE UDZIELANIA PIERWSZEJ POMOCY
}

\section{THE LEVEL OF KNOWLEDGE OF MEDICAL AND NON-MEDICAL STUDENTS IN THE FIELD OF FIRST AID}

\author{
Ewelina Nowak ${ }^{1}$, Monika Pierzak ${ }^{2}$ \\ ${ }^{1}$ Zakład Chorób Wewnętrznych, Kardiologii i Pielęgniarstwa Internistycznego \\ Instytut Pielęgniarstwa i Położnictwa, Wydział Lekarski i Nauk o Zdrowiu, Uniwersytet Jana Kochanowskiego w Kielcach \\ ${ }^{2}$ Zakład Medycyny Rodzinnej i Geriatrii, Instytut Nauk Medycznych, Wydział Lekarski i Nauk o Zdrowiu \\ Uniwersytet Jana Kochanowskiego w Kielcach
}

DOI: https://doi.org/10.20883/pielpol.2018.8

\section{STRESZCZENIE}

Wstęp. Pierwsza pomoc to zespół czynności podejmowanych w celu ratowania osoby w stanie nagłego zagrożenia zdrowotnego wykonywanych przez osobę znajdującą się na miejscu zdarzenia, w tym również z wykorzystaniem udostępnionych do powszechnego obrotu wyrobów medycznych oraz produktów leczniczych. Cel badania to pomiar oraz ocena poziomu wiedzy studentów studiów medycznych i niemedycznych dotyczącej zasad i umiejętności praktycznych udzielenia pierwszej pomocy.

Materiał i metody. Badanie przeprowadzono od grudnia $2016 \mathrm{r}$. do lutego 2017 r. na Uniwersytecie Jana Kochanowskiego oraz Politechnice Świętokrzyskiej w Kielcach. W badaniu wzięło udział 137 studentów. W pracy wykorzystano metodę sondażu diagnostycznego. Techniką, którą się posłużono, była technika ankiety. Wyniki. Poziom wiedzy studentów uzależniony jest od wielu czynników, wśród których zasadniczą rolę odgrywają: doświadczenie oraz profil kierunków studiów. Porównywane grupy studentów cechowały się różną wiedzą w zakresie udzielania pierwszej pomocy. Jak wskazywały średnie (M), studenci studiów medycznych prezentują wyższy poziom tej wiedzy $(M=10,21)$ niż studenci studiów niemedycznych $(M=8,35)$.

Wnioski. Profil kierunku studiów ma decydujący wpływ na poziom wiedzy oraz umiejętności z zakresu pierwszej pomocy. Studenci studiów zarówno medycznych, jak i niemedycznych bezwzględnie powinni być zobowiązani do uczestnictwa w zajęciach kształcących wiedzę oraz umiejętności praktyczne z zakresu pierwszej pomocy.

SŁOWA KLUCZOWE: pierwsza pomoc, poziom wiedzy, studenci.

\section{Wprowadzenie}

Zgodnie z "Ustawą z dnia 8 września 2006 r. o Państwowym Ratownictwie Medycznym" (Dz.U.06.191.1410) pierwsza pomoc to zespół czynności podejmowanych w celu ratowania osoby w stanie nagłego zagrożenia

\begin{abstract}
Introduction. First aid is the assistance given to any person suffering sudden illness or injury at the place of occurrence including the use of commercially available medical devices and pharmaceutical medicines. The purpose of the study is to measure and assess the level of knowledge of medical and non-medical students concerning the principles and practical skills of first aid. Material and methods. The research was conducted from December 2016 to February 2017 at Jan Kochanowski University and University of Technology in Kielce. The study involved 137 students. The diagnostic survey method and the questionnaire were used in the study.

Results. The level of students' knowledge depends on factors among which the main role is played by experience and the field of study. These two groups of students were characterized by different levels of first aid knowledge. As indicated by the average (M), students of medical studies have a higher level of first aid knowledge ( $M=10.21)$ than non-medical students $(M=8.35)$.

Conclusions. The field of study plays a major role in the level of knowledge and skills in the first aid. Both students of medical and non-medical studies should attend classes that enhance their knowledge and skills in the first aid.
\end{abstract}

KEYWORDS: first aid, level of knowledge, students.

zdrowotnego wykonywanych przez osobę znajdującą się w miejscu zdarzenia, w tym również z wykorzystaniem udostępnionych do powszechnego obrotu wyrobów medycznych oraz produktów leczniczych [1]. Udzielenie pierwszej pomocy jest prawnym obowiązkiem każde- 
go, niezależnie od przekonań czy wyznań. O obowiązku udzielenia pierwszej pomocy mówi artykuł 4 "Ustawy (...) o Państwowym Ratownictwie Medycznym": „Kto zauważy osobę lub osoby znajdujące się w stanie nagłego zagrożenia zdrowotnego lub jest świadkiem zdarzenia powodującego taki stan, w miarę posiadanych możliwości i umiejętności ma obowiązek niezwłocznego podjęcia działań zmierzających do skutecznego powiadomienia o tym zdarzeniu podmiotów ustawowo powołanych do niesienia pomocy osobom w stanie nagłego zagrożenia zdrowotnego" [1]. Jest to także obowiązek moralny, bo kto oczekuje tej pomocy od innych, musi być w stanie sam tę pomoc świadczyć. Konieczne jest więc, aby jak najwięcej osób znało zasady pierwszej pomocy i mogło jej fachowo udzielić, zanim zjawi się wykwalifikowany personel medyczny [2, 3]. Niezaprzeczalnym prawem każdego człowieka, który znalazł się w sytuacji nagłego zagrożenia zdrowia lub życia, jest otrzymanie, w możliwie najkrótszym czasie, specjalistycznej oraz wysoko zaawansowanej pomocy lekarskiej, której celem staje się opanowanie nagłego zagrożenia, utrzymanie i ustabilizowanie funkcji życiowych, zmniejszenie bólu i cierpienia oraz w razie konieczności kontynuowanie leczenia specjalistycznego [4, 5]. Ważnym staje się fakt, aby osoba udzielająca pierwszej pomocy przestrzegała podstawowych zasad zapewniających bezpieczeństwo ratującemu i poszkodowanemu oraz dającemu choremu szansę na przywrócenie zdrowia, a nawet życia [2]. Należy postępować zgodnie z maksymą „po pierwsze nie szkodzić”. Każda przypadkowa osoba podejmująca działania ratownicze powinna przestrzegać podstawowych zasad; ocenić sytuację wraz z bezpieczeństwem, udzielić pierwszej pomocy, zapewnić dalszą opiekę poszkodowanemu i przekazać informacje o poszkodowanym zespołowi ratownictwa medycznego [5, 6]. Podjęcie działań pierwszej pomocy to jedyny sposób uniknięcia prawnej odpowiedzialności za nieudzielenie pomocy osobie znajdującej się w położeniu grożącym bezpośrednim niebezpieczeństwem utraty życia lub ciężkiego uszczerbku na zdrowiu [7-9].

Cel badania to pomiar oraz ocena poziomu wiedzy studentów studiów medycznych i niemedycznych dotyczącej zasad i umiejętności praktycznych udzielenia pierwszej pomocy. Analizie poddano również zależności między płcią, wiekiem, miejscem zamieszkania i doświadczeniami związanymi z udzielaniem pierwszej pomocy.

\section{Materiał i metody}

Badanie przeprowadzono od grudnia 2016 r. do lutego 2017 r. na Uniwersytecie Jana Kochanowskiego (Wydział Lekarski i Nauk o Zdrowiu, Humanistyczny i Matematyczno-Przyrodniczy) oraz Politechnice Świę- tokrzyskiej w Kielcach. W badaniu wzięło udział 137 studentów. Studentów studiów medycznych było 77 (Wydział Lekarski i Nauk o Zdrowiu UJK), studentów studiów niemedycznych było 60 (Politechnika Świętokrzyska - 29 osób, Wydział Matematyczno-Przyrodniczy UJK - 27 osób, Wydział Humanistyczny UJK - 4 osoby). Wśród respondentów było 107 kobiet i 30 mężczyzn. Respondenci różnili się od siebie miejscem zamieszkania: 85 spośród studentów biorących udział w badaniu mieszkało na wsi, 27 osób - w mieście powyżej 100 tys. mieszkańców, natomiast 23 osoby zamieszkiwały miasto mniejsze niż 100 tys. mieszkańców. Studenci biorący udział w badaniu byli w wieku mieszczącym się w przedziale od 19. do 29. roku życia, spośród nich najliczniejszą grupe stanowiły osoby w wieku 21 lat, natomiast najmniej liczną stanowili studenci w 19. oraz 29. roku życia.

Do przeprowadzenia badania stworzono autorski, anonimowy kwestionariusz, który składał się z 23 pytań. Pierwsza część ankiety dotyczyła danych demograficznych: płci, wieku, miejsca zamieszkania oraz miejsca studiowania. Druga część, składająca się z 14 pytań, miała na celu określenie poziomu wiedzy na temat udzielania pierwszej pomocy. Pytania zostały stworzone na podstawie aktualnych wytycznych Europejskiej Rady Resuscytacji [17]. Studentom zadano również pytania dotyczące prób i doświadczeń związanych z udzielaniem pierwszej pomocy, uczestnictwa w zajęciach z pierwszej pomocy oraz znajomości zagadnień prawnych dotyczących udzielania i zaniechania pierwszej pomocy. Poziom wiedzy studentów został sklasyfikowany za pomocą punktacji wyrażonej w liczbach. Przedstawia się on następująco: 20 pkt - poziom wiedzy wysoki, 13 pkt - poziom wiedzy średni, $\geqslant 12$ pkt - poziom wiedzy niski.

Kwestionariusz ankiety respondenci wypełniali osobiście w obecności autorów pracy. Zapewniło to anonimowość i rzetelność badania. Uzyskane przez uczestników wyniki zostały zliczone pod względem ilościowym, a następnie zilustrowane w tabelach. Wyniki badań zostały poddane analizie przy użyciu pakietu IBM SPSS Statistics 23. Za jego pomocą wykonano analizę podstawowych statystyk opisowych wraz z testem Kołmogorowa-Smirnowa, test t-studenta dla prób niezależnych, jednoczynnikowe analizy wariancji dla prób niezależnych testu Manna-Whitneya oraz analizę korelacji ze współczynnikiem $r$ Pearsona. Za poziom istotności w niniejszej pracy uznano $p<0,05$. Wyniki istotne na poziomie $0,05<p<0,1$ uznawano za istotne na poziomie tendencji statystycznej.

\section{Wyniki}

W pierwszym kroku przeprowadzono analize podstawowych statystyk opisowych wraz z testem Kołmogorowa-Smirnowa badającym normalność rozkładu 
mierzonych zmiennych ilościowych. W jego wyniku okazało się, że zarówno dla ogółu badanych, jak i w grupie studentów studiów medycznych i niemedycznych rozkłady wiedzy z zakresu udzielania pierwszej pomocy są zgodne z rozkładem normalnym. Dlatego też podjęto decyzję, by przeprowadzić parametryczne testy i analizy w niniejszej pracy. Zbiorczo wyniki wszystkich wyliczonych statystyk opisowych wraz z testem normalności rozkładu zawiera tabela 1.

Tabela 1. Poziom wiedzy studentów dotyczącej udzielania pierwszej pomocy

Table 1. Knowledge level of first aid students

\begin{tabular}{cccccccccc}
\hline & M & Mdn & SD & Sk. & Kurt. & Min. & Maks. & K-S & P \\
\hline $\begin{array}{c}\text { Ogółem/ } \\
\text { Altogether }\end{array}$ & 9,39 & 10,00 & 2,53 & $-0,19$ & $-0,53$ & 3,00 & 15,00 & 1,19 & 0,116
\end{tabular}

Studenci studiów

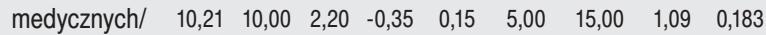
Medical students

Studenci studiów

niemedycznych/

Students of non-

medical studies

M - średnia/average; Mdn - mediana/median; SD - odchylenie standardowe/standard deviation; Sk. - skośność/slant; Kurt. - kurtoza/ kurtosis; K-S - wynik testu Kołmogorowa-Smirnowa/result of the test Kołmogorowa-Smirnowa; P - istotność/relevance

Źródło: opracowanie własne

Source: author's own analysis

\section{Związek pomiędzy profilem kierunku studiów a wiedzą z zakresu pierwszej pomocy}

W kolejnym kroku przeprowadzanych analiz wykonano test t-studenta dla prób niezależnych. Przy jego użyciu porównano studentów studiów medycznych $(n=77)$ ze studentami studiów niemedycznych $(n=60)$ pod względem ich poziomu wiedzy na temat udzielania pierwszej pomocy. Wynik, jaki uzyskano, okazał się być istotny statystycznie $-\mathrm{t}(135)=4,56 ; \mathrm{p}<0,001 ; 95 \%$ CI $[1,05 ; 2,66] ; d=0,79$, a zatem porównywane grupy studentów cechują się różną wiedzą w zakresie udzielania pierwszej pomocy. Jak wskazują średnie, studenci studiów medycznych mają jej wyższy poziom $(M=10,21$; $\mathrm{SD}=2,20)$ niż studenci studiów niemedycznych $(\mathrm{M}=8,35$;
$S D=2,57)$. Według miary siły efektu różnic d-Cohena różnice te są o dużej sile. Graficzne przedstawienie wyników zawiera rycina 1.

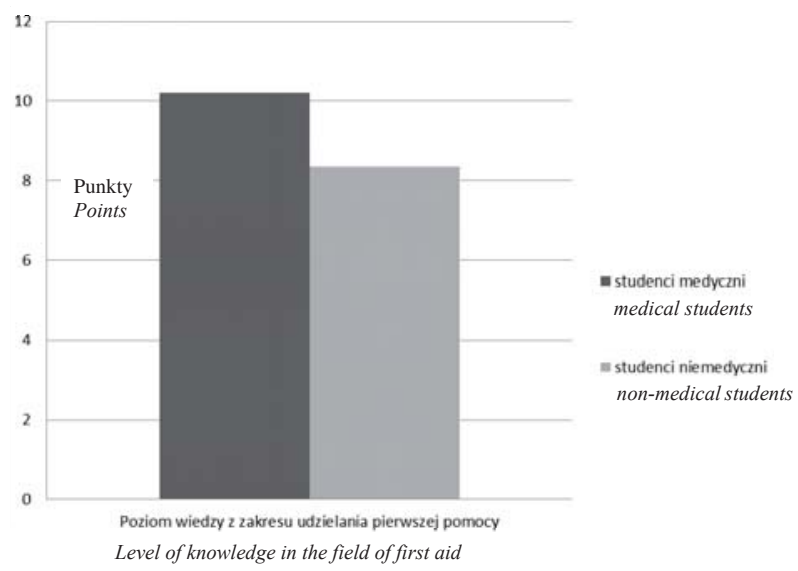

Rycina 1. Porównanie średniego poziomu wiedzy z zakresu udzielania pierwszej pomocy w zależności od rodzaju studiów

Figure 1. Comparison of the average level of first aid knowledge depending on the type of study

Źródło: opracowanie własne

Source: author's own analysis

\section{Związek pomiędzy miejscem zamieszkania a wiedzą respondentów dotyczącą pierwszej pomocy}

W kolejnym kroku, przy użyciu testu t-studenta dla prób niezależnych, zbadano istotność wpływu miejsca zamieszkania na poziom wiedzy dotyczącej udzielania pierwszej pomocy. Porównano do siebie mieszkańców miast powyżej 100 tys. mieszkańców ( $n=23$ ), mieszkańców miast poniżej 100 tys. mieszkańców ( $n=23)$, a także mieszkańców wsi $(n=85)$. W wyniku przeprowadzonej analizy okazało się jednak, że grupy te nie różnią się pomiędzy sobą pod względem mierzonego poziomu wiedzy $-F(2,134)=1,86 ; p=0,160$; $c^{2}=0,03$. Zarówno mieszkańcy miast powyżej 100 tys. mieszkańców ( $M=9,65 ; S D=2,23$ ), poniżej 100 tys. mieszkańców ( $M=10,11$; $S D=2,65)$, jak i mieszkańcy wsi $(M=9,08$; $S D=2,56)$ mają podobny do siebie poziom wiedzy z zakresu udzielania pierwszej pomocy. Graficzne przedstawienie wyników zawiera rycina 2. 


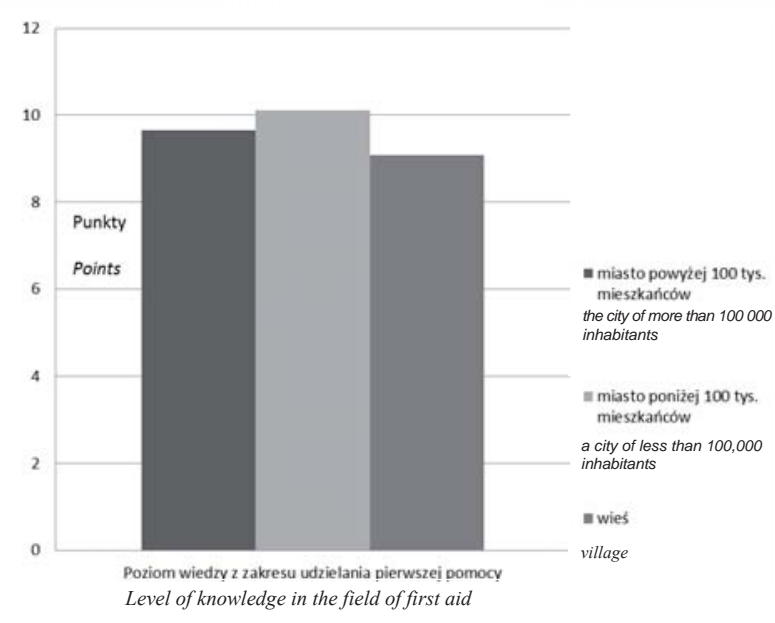

Rycina 2. Porównanie średniego poziomu wiedzy z zakresu udzielania pierwszej pomocy w zależności od miejsca zamieszkania badanych Figure 2. Comparison of the average level of first aid knowledge depending on the respondents' residence

Źródło: opracowanie własne

Source: author's own analysis

\section{Związek pomiędzy płcią a poziomem wiedzy z zakresu pierwszej pomocy}

Następnie przeprowadzony został test Manna-Whitneya w celu zbadania, czy płeć różnicuje istotnie statystycznie badaną próbę pod względem poziomu wiedzy dotyczącej pierwszej pomocy. Wybór nieparametrycznej analizy został podyktowany faktem, iż zaobserwowano dość znaczącą rozbieżność w liczebnościach badanych kobiet $(n=107)$ oraz mężczyzn $(n=30)$. Jednakże wynik tej analizy okazał się być nieistotny statystycznie $Z=-0,10 ; p=0,921 ; r=0,01$, a co za tym idzie - brak jest zróżnicowania międzypłciowego w zakresie poziomu mierzonej wiedzy. Poziom wiedzy kobiet $(M=9,36$; $S D=2,58 ; M d n=10,00)$ jest zbliżony do średniego poziomu mężczyzn ( $M=9,53 ; \mathrm{SD}=2,39$; $\mathrm{Mdn}=9,00$ ). Graficzne przedstawienie wyników zawiera rycina 3.

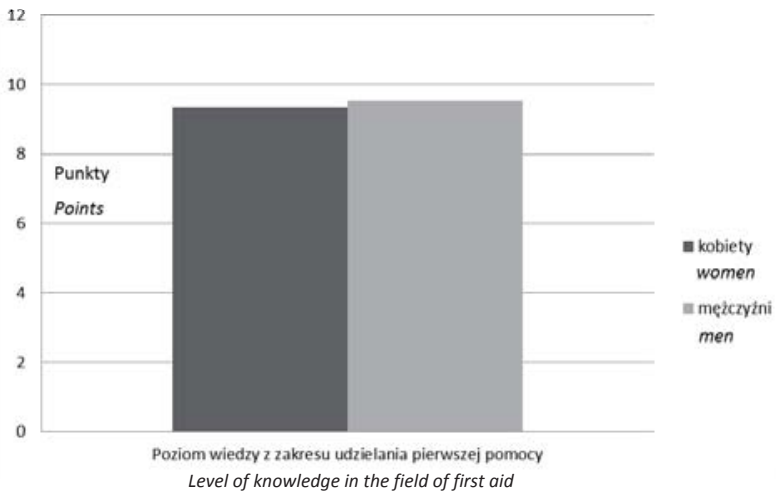

Rycina 3. Porównanie średniego poziomu wiedzy z zakresu udzielania pierwszej pomocy w zależności od płci badanych

Figure 3. Comparison of the average level of first aid knowledge depending on the sex of the respondents

Źródło: opracowanie własne

Source: author's own analysis

\section{Związek pomiędzy wiekiem badanych respondentów a poziomem wiedzy z zakresu pierwszej pomocy}

W kolejnym kroku przeprowadzona została natomiast analiza korelacji ze współczynnikiem $r$ Pearsona. Za jej pomocą zbadano, czy wiek koreluje istotnie statystycznie z poziomem wiedzy badanych na temat udzielania pierwszej pomocy. Przed wyborem rodzaju analizy zbadano zgodność rozkładu wieku z rozkładem normalnym. Okazało się, że wynik testu Kołmogorowa-Smirnowa jest istotny statystycznie $-\mathrm{K}-\mathrm{S}=2,32$; $p<0,001$, a także skośność $(S k .=1,01)$ tej zmiennej przekracza umowną wartość bezwzględną 0,08, co potwierdza asymetrię względem rozkładu normalnego. Sprawdzono także obecność obserwacji odstających i odnotowano dwie obserwacje w wieku 29 lat, które odbiegały od reszty próby. Po odfiltrowaniu tych dwóch obserwacji wynik testu Kołmogorowa-Smirnowa pozostał istotny statystycznie - K-S $=2,43$; $p<0,001$, niemniej jednak wartość skośności zmalała do satysfakcjonującego poziomu równego 0,47. Stąd też decyzja o przeprowadzeniu parametrycznej analizy z zachowaniem odfiltrowanych dwóch badanych w wieku 29 lat. Wynik przeprowadzonej analizy korelacji okazał się być jednak nieistotny statystycznie $-r=-0,09 ; p=0,287$, co oznacza, że wiek nie ma związku z poziomem wiedzy badanych na temat udzielania pierwszej pomocy.

\section{Zależność pomiędzy poziomem wiedzy respondentów z zakresu pierwszej pomocy a udzieloną kiedykolwiek pierwszą pomocą poszkodowanym}

W dalszej części analiz wykonany został test Manna-Whitneya mający na celu porównanie badanych, którzy kiedykolwiek wcześniej udzielili pierwszej pomocy ( $n=102$ ) oraz tych, którzy tego nie robili $(n=35)$. Wybór nieparametrycznej analizy ponownie został podyktowany faktem zbyt różnych liczebności obu grup. W wyniku przeprowadzonej analizy uzyskano istotne różnice pomiędzy porównywanymi grupami $-Z=-2,97 ; p<0,01$; $r=0,25$. Średnie wskazują, że badani, którzy mają już doświadczenie z udzielaniem pierwszej pomocy, mają również wyższy poziom wiedzy $(M=10,54$; $S D=2,41$; Mdn = 11,00) aniżeli badani, którzy wcześniej tego nie robili $(M=9,00 ; S D=2,47 ; M d n=9,00)$. $Z$ kolei miara siły efektu różnic $r$ dowodzi, że uzyskane różnice mają umiarkowaną siłę. Graficzne przedstawienie wyników zawiera rycina 4. 


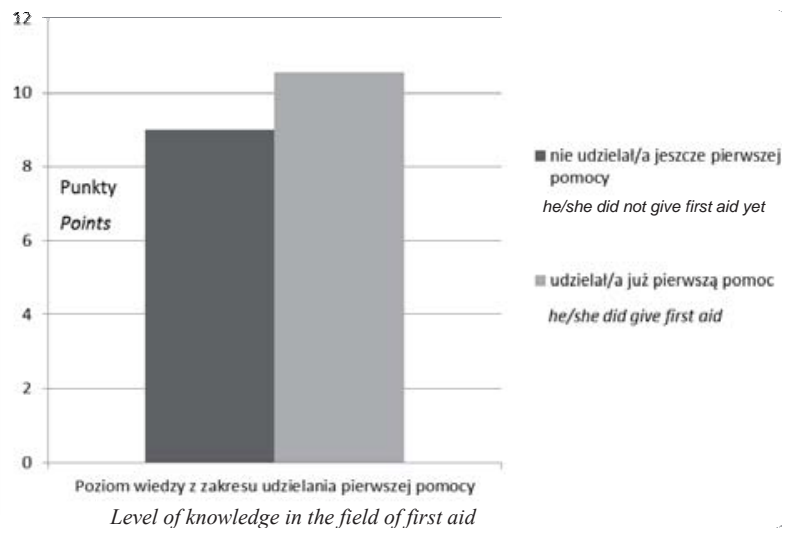

Rycina 4. Porównanie średniego poziomu wiedzy z zakresu udzielania pierwszej pomocy w zależności od doświadczenia w udzielaniu pierwszej pomocy

Figure 4. Comparison of the average level of first aid knowledge depending on experience in first aid

Źródło: opracowanie własne

Source: author's own analysis

\section{Dyskusja}

Procedury medyczne, które świadczone są przez Państwowe Ratownictwo Medyczne, często postrzegane są przez społeczeństwo jako szereg skomplikowanych czynności, które wykonywać mogą tylko osoby z wykształceniem medycznym. Z powodu takich przekonań świadkowie zdarzeń, w których należy udzielić pierwszej pomocy, nie czynią tego z obawy przed nieumiejętnym udzieleniem pomocy. Niezwykle ważnym staje się fakt, iż za nieudzielenie poszkodowanej osobie pomocy grozi kara, o czym mówi „Ustawa z dnia 6 czerwca 1997 r. Kodeks karny" (Dz.U. 97.88.553); art. 162: „Kto człowiekowi znajdującemu się w położeniu grożącym bezpośrednim niebezpieczeństwem utraty życia albo ciężkiego uszczerbku na zdrowiu nie udziela pomocy, mogąc jej udzielić bez narażenia siebie lub innej osoby na niebezpieczeństwo utraty życia albo ciężkiego uszczerbku na zdrowiu, podlega karze pozbawienia wolności do lat 3" [10].

Brak wystarczającej wiedzy z pierwszej pomocy wśród studentów kształcących się na kierunkach niemedycznych przemawia za koniecznością efektywnego i intensywnego nauczania podstawowych zasad i technik pierwszej pomocy. Życie i zdrowie człowieka jest wartością bezcenną. Przypadkowi świadkowie zdarzenia, którzy zastosują algorytm resuscytacji krążeniowo-oddechowej z użyciem automatycznego defibrylatora zewnętrznego (ang. automated external defibrillator - AED), przed przybyciem zespołu ratownictwa medycznego, często odgrywają kluczową rolę w ratowaniu życia poszkodowanego, u którego doszło do nagłego zatrzymania krążenia [11].
Z badań Chemperek i wsp. wynika, że stan wiedzy respondentów z zakresu pierwszej pomocy jest niezadowalający. Duża grupa ankietowanych nie zna aktualnych wytycznych Europejskiej Rady Resuscytacji [12]. Podobne wyniki przedstawiają Skitek i wsp. $\mathrm{Na}$ podstawie przeprowadzonego badania stwierdzili, że poziom wiedzy z zakresu pierwszej pomocy wśród osób studiujących kierunki niemedyczne jest niewystarczający. Studenci studiów medycznych w większości mają wiedzę z zakresu pierwszej pomocy [13]. Wyniki przeprowadzonych badań własnych oraz badań autorów prac podejmujących tematykę udzielania pierwszej pomocy potwierdzają występowanie pilnej potrzeby wprowadzenia komplementarnego i systematycznego nauczania zagadnień z pierwszej pomocy. Znajomość aktualnych wytycznych Europejskiej Rady Resuscytacji i aktów prawnych regulujących obowiązek udzielania pierwszej pomocy zagwarantuje pozytywną postawę niesienia pomocy $[14,15]$.

Wiedza studentów studiów medycznych jest wyższa niż wiedza studentów niemedycznych. Jak wskazują średnie, studenci studiów medycznych mają jej wyższy poziom $(M=10,21$; $S D=2,20)$ niż studenci studiów niemedycznych $(M=8,35$; $S D=2,57$ ). Istotnym staje się fakt, iż różnica w wiedzy studentów jest mało zróżnicowana. Studenci kształcący się na kierunkach medycznych - ze względu na specyfikę zawodu, który będą wykonywać w przyszłości - powinni charakteryzować się najwyższym poziomem wiedzy i umiejętności mających służyć zdrowiu oraz życiu drugiego człowieka. Podobne wyniki badań otrzymali Seweryn i wsp.; autorzy stwierdzili, że wiedza studentów (z wyłączeniem kierunku: ratownictwo medyczne) nie jest znacząco różna od wiedzy studentów kierunków humanistycznych i nauk o bezpieczeństwie [16, 17].

Wiedza studentów studiów medycznych oraz niemedycznych nie jest zależna do miejsca zamieszkania, płci oraz wieku. Zarówno mieszkańcy miast powyżej 100 tys. mieszkańców ( $M=9,65$; $S D=2,23)$, poniżej 100 tys. mieszkańców ( $M=10,11$; $S D=2,65$ ), jak i mieszkańcy wsi $(M=9,08 ; S D=2,56)$ mają podobny do siebie poziom wiedzy z zakresu udzielania pierwszej pomocy. Poziom wiedzy kobiet $(M=9,36$; $S D=2,58$; Mdn $=10,00$ ) jest zbliżony do średniego poziomu wiedzy mężczyzn ( $M=9,53$; SD = 2,39; $M d n=9,00)$.

Doświadczenie w udzielaniu pierwszej pomocy odgrywa zasadniczą rolę w decyzyjności osoby ratującej. Badanie ankietowanych wskazuje, iż osoby, które mają już doświadczenie z udzielaniem pierwszej pomocy, mają również wyższy poziom wiedzy $(\mathrm{M}=10,54$; $\mathrm{SD}=2,41 ; \mathrm{Mdn}=11,00)$ aniżeli badani, którzy wcześniej nie udzielali pierwszej pomocy $(M=9,00$; $S D=2,47$; $\operatorname{Mdn}=9,00)$. 
Budowanie świadomości społeczeństwa o przydatności wiedzy z pierwszej pomocy można realizować poprzez wprowadzanie tych zagadnień w różne obszary życia. Ważne jest, aby na uczelniach wprowadzić projekt edukacyjno-informacyjny, który byłby ukierunkowany na zmianę świadomości i podniesienie poziomu wiedzy społeczeństwa, zwłaszcza ludzi młodych, na temat udzielania pierwszej pomocy.

\section{Wnioski}

1. Profil kierunku studiów ma decydujący wpływ na poziom wiedzy oraz umiejętności z zakresu pierwszej pomocy. Wprowadzenie dodatkowych zajęć z pierwszej pomocy na uczelniach o profilu niemedycznym wydaje się być koniecznością wynikającą z niskiego poziomu wiedzy.

2. Wskazane jest udoskonalenie metod nauczania wśród studentów studiów medycznych i niemedycznych, co pozwoli na lepsze przygotowanie do możliwej konfrontacji z sytuacjami zagrożenia dla zdrowia i życia człowieka. Bezwzględnym obowiązkiem powinno być uczestnictwo w zajęciach kształcących wiedzę oraz umiejętności praktyczne.

3. Niepokojącym faktem jest niski poziom wiedzy studentów studiów medycznych, którzy ze względu na profil kierunków studiów oraz rodzaj przyszłego zawodu powinni prezentować wysoki poziom wiedzy z zakresu metod i technik udzielania pierwszej pomocy.

4. Szkolenia obejmujące zajęcia teoretyczne i praktyczne z zakresu udzielania pierwszej pomocy powinny być organizowane cyklicznie na każdym szczeblu kształcenia akademickiego. Prowadzenie zajęć powinno być powierzone nauczycielom posiadającym odpowiednie kwalifikacje oraz aktualne certyfikaty pierwszej pomocy.

5. Wiedza, która jest przekazywana studentom studiów zarówno medycznych, jak i niemedycznych, powinna opierać się na aktualnych wytycznych Europejskiej Rady Resuscytacji.

\section{Piśmiennictwo}

1. Ustawa z dnia 8 września 2006 r. o Państwowym Ratownictwie Medycznym. Dz.U.06.191.1410 z późn. zm.

2. Ustawa z dnia 23 kwietnia 1964 r. Kodeks cywilny. Dz.U.64.16.93 z późn. zm.

3. Europejska Rada Resuscytacji. Wytyczne resuscytacji 2015.

4. Stammet P, Collas D, Werer $C$ et al. Impact of initial intervention on long-term neurological recovey after cardiac ar- rest: data from the Luxembourg 'North Pole' cohort. Bull Soc Sci Med Grand Duche Luxemb. 2012; 1: 60-70.

5. Goniewicz M. Pierwsza pomoc. Podręcznik dla studentów. Warszawa: PZWL; 2011.

6. Adielsson A, Hollenberg J, Karlsson T et al. Increase in survival and bystander CPR in out-of-hospital shockable arrhythmia: bystander CPR and female gender are predictors of improved outcome. Experiences from Sweden in an 18-year perspective. Heart. 2011; 97(17): 1391-1396.

7. Ustawa z dnia 20 maja 1971 r. Kodeks wykroczeń. Dz.U.71.109.756.

8. Ustawa z dnia 20 czerwca 1997 r. Prawo o ruchu drogowym. Dz.U. 05.108.908 z późn. zm.

9. Ustawa z dnia 26 czerwca 1974 r. Kodeks pracy. Dz.U.98.21.94 z późn. zm.

10. Ustawa $z$ dnia 6 czerwca 1997 r. Kodeks karny. Dz.U.97.88.553.

11. Europejska Rada Resuscytacji, Polska Rada Resuscytacji (tłum.). Wytyczne resuscytacji 2015. Kraków: Polska Rada Resuscytacji; 2015.

12. Chemperek E, Goniewicz M, Włoszczak-Szubzda A et al. Poziom wiedzy uczniów szkół ponadgimnazjalnych i studentów w zakresie pierwszej pomocy. Med Ogólna Nauki Zdr. 2011; 1(4): 174-179.

13. Skitek I, Witt M, Goniewicz M. Ocena znajomości zagadnień z pierwszej pomocy wśród studentów uczelni uniwersyteckich miasta Poznania. Now Lek. 2012; 81, 6: 641-646.

14. Olejniczak D, Miciuk D, Religioni U. Ocena stanu wiedzy studentów Warszawskiego Uniwersytetu Medycznego na kierunku pielęgniarstwo na temat pierwszej pomocy przedmedycznej. Piel Zdr Publ. 2013; 3: 101-110.

15. Metin I, Mutlu C. Level of knowledge about first aid of the university students. Trakia J Sci. 2010; 8: 262-265.

16. Patryn R, Żyśko M, Sobczyńska M. Analiza poziomu wiedzy i znajomości prawa dotyczącego zasad udzielania pierwszej pomocy wśród grupy aktywnych kierowców województwa lubelskiego. Med Ogólna Nauki Zdr. 2012; 18, 4: 324-329.

17. Seweryn B, Spodaryk M, Ziarko A. Stan wiedzy studentów o zasadach udzielania pierwszej pomocy i systemie Państwowego Ratownictwa Medycznego w Polsce. Państwo i Społeczeństwo. 2016; 16, 4: 70-86.

Artykuł przyjęty do redakcji: 05.5.2017

Artykuł przyjęty do publikacji: 23.08.2017

Źródło finansowania: Praca nie jest finansowana z żadnego źródła. Konflikt interesów: Autorzy deklarują brak konfliktu interesów.

Adres do korespondencji:

Ewelina Nowak

al. IX Wieków Kielc 19

25-317 Kielce

tel.: 413496935

e-mail: ewelinanowakkielce@gmail.com

Zakład Chorób Wewnętrznych, Kardiologii i Pielęgniarstwa Internistycznego

Instytut Pielęgniarstwa i Położnictwa, Wydział Lekarski i Nauk o Zdrowiu Uniwersytet Jana Kochanowskiego w Kielcach 